\title{
Pengaruh insektisida deltametrin terhadap perilaku orientasi parasitoid Anagrus nilaparvatae (Pang et Wang) (Hymenoptera: Mymaridae)
}

\author{
Effects of deltamethrin insecticide on \\ the orientation behaviour of Anagrus nilaparvatae \\ (Pang et Wang) (Hymenoptera: Mymaridae) parasitoid \\ Araz Meilin $^{*}$, Y. Andi Trisyono ${ }^{2}$, Edhi Martono $^{2}$, Damayanti Buchori $^{3}$ \\ ${ }^{1}$ Balai Pengkajian Teknologi Pertanian Jambi \\ Jalan Samarinda, Paal Lima, Kota Baru, Jambi 36128 \\ ${ }^{2}$ Jurusan Hama dan Penyakit Tumbuhan, Fakultas Pertanian, Universitas Gadjah Mada \\ Jalan Flora No.1 Bulak Sumur, Yogyakarta 55281 \\ ${ }^{3}$ Departemen Proteksi Tanaman, Fakultas Pertanian, Institut Pertanian Bogor \\ Jalan Kamper, Kampus IPB Dramaga, Bogor 16680
}

(diterima Desember 2014, disetujui Juli 2015)

\begin{abstract}
ABSTRAK
Perilaku pencarian inang oleh parasitoid mencakup juga perilaku orientasi terhadap senyawa volatil (bau) inang atau tanaman inang. Penelitian ini bertujuan untuk mengetahui perubahan perilaku orientasi parasitoid Anagrus nilaparvatae (Pang et Wang) yang terpapar insektisida deltametrin dengan konsentrasi subletal dan residu deltametrin pada tanaman padi terhadap penemuan inang oleh parasitoid. Konsentrasi subletal deltametrin $0,023 \mathrm{ppm}\left(\mathrm{LC}_{10}\right)$ dan 2,235 ppm $\left(\mathrm{LC}_{40}\right)$ secara kontak diaplikasikan pada parasitoid $A$. nilaparvatae. Konsentrasi deltametrin yang diaplikasikan pada tanaman padi adalah 12,5 ppm dan 6,25 ppm. Residu yang diuji adalah 3 jam, 1 hari, 3 hari, dan 7 hari setelah aplikasi. Perilaku orientasi diuji dengan menggunakan olfaktometer tabung-Y. Deltametrin konsentrasi subletal pada parasitoid dan tanaman padi menurunkan kemampuan orientasi parasitoid A. nilaparvatae untuk menemukan tanaman yang mengandung inang Nilaparvata lugens (Stål). Semakin tinggi konsentrasi perlakuan deltametrin baik yang diperlakukan pada parasitoid maupun tanaman maka pengaruhnya terhadap perubahan orientasi semakin besar dan gangguan terhadap orientasi $A$. nilaparvatae dalam menemukan inang semakin besar. Efek subletal insektisida pada parasitoid dan tanaman padi akhirnya menyebabkan parasitoid $A$. nilaparvatae menjadi kurang efektif sebagai agens pengendali hayati di lapangan karena menurunnya performa dalam memarasit dan menyerang inangnya.
\end{abstract}

Kata kunci: olfaktometer, piretroid, sub lethal, wereng batang cokelat

\begin{abstract}
Host searching behaviour by a parasitoid includes orientation to the volatile compounds (odor) relesead by host or host plant. The aim of this study was to determine the changes in the orientation behaviour of Anagrus nilaparvatae (Pang et Wang), the egg parasitoid of rice brown planthoppers (Nilaparvata lugens (Stål)), after being exposed to sublethal concentrations of deltamethrin. The impact of residue on plants to the behaviour of parasitoid was also studied. The sublethal concentrations $\left(\mathrm{LC}_{10}\right.$ and $\left.\mathrm{LC}_{40}\right)$ used were $0.023 \mathrm{ppm}$ and $2.235 \mathrm{ppm}$, respectively. Deltamethrin
\end{abstract}


applied to the rice plants were $12.5 \mathrm{ppm}$ and $6.25 \mathrm{ppm}$, and its effect was observed at 3 hours, 1, 3 and 7 days after application. Orientation behavior was studied using Y-tube olfactometer. Application of deltamethrin at subletal concentration reduced the ability of surviving $A$. nilaparvatae to detect odors (volatile ompounds) released by the host, $N$. lugens. The higher the concentration of deltamethrin applied to the parasitoid or to the rice plants, the more prominent effect observed in the changing in the parasitoid behavious, in particular disruption to the parasitoid's orientation to find their host. As consequences, effects of deltamethrin may lead to reduce the effectiveness of $A$. nilaparvatae as biological control agents in the field as a result of declining their searching capacity.

Key words: olfaktometer, piretroid, rice brown planthoppers, sub lethal

\section{PENDAHULUAN}

Keefektifan parasitoid dalam pengendalian hayati sebagian besar bergantung pada kemampuan parasitoid untuk menemukan, mengenali dan memarasit inangnya. Keberhasilan parasitasi dimediasi oleh berbagai rangsangan bahan kimia dan fisik pada lokasi habitat inang, lokasi inang, penerimaan inang, kesesuaian inang dan pengaturan inang (Nordlund 1994; Vinson 1976; Vinson 1998). Perilaku pencarian inang mencakup orientasi terhadap bau inang dan tanaman-inang (Vinson 1998). Semua perilaku yang terlibat dalam proses tersebut melibatkan fungsi sistem saraf serangga. Oleh karena itu, insektisida yang bekerja pada sistem saraf, misalnya piretroid, dapat berpengaruh terhadap proses penemuan/ penerimaan inang (Delpuech et al. 1999; Salerno et al. 2002).

Parasitoid Anagrus nilaparvatae (Pang et Wang) (Hymenoptera: Mymaridae) merupakan parasitoid pada telur Nilaparvata lugens (Stal.) (Homoptera: Delphacidae) dan telah dilaporkan terdapat di Cianjur, Jawa Barat, Indonesia sejak tahun 1993 (Triapitsyn \& Berezovskiy 2004). Penelitian aspek biologi, ekologi maupun dampak insektisida terhadap $A$. nilaparvatae belum pernah dilaporkan di Indonesia.

Deltametrin merupakan salah satu insektisida piretroid yang masih banyak digunakan di Indonesia, dan dapat dijadikan sebagai model dalam penelitian ini. Aplikasi insektisida piretroid secara terus menerus dapat menyebabkan polusi insektisida pada lingkungan. Polusi ini dapat menghambat perkembangan populasi serangga (Delpuech et al. 2001) melalui gangguan sistem syaraf(Desneux et al. 2007). Konsentrasi atau dosis subletal insektisida dapat menyebabkan mortalitas atau perubahan biologi dan perilaku serangga melalui gangguan sistem syaraf (Haynes 1998;
Desneux et al. 2007; Garcia 2011). Deltametrin konsentrasi subletal mempengaruhi respons perilaku pencarian inang parasitoid Trissolcus basalis (Wollaston) (Hymenoptera: Scelionidae) terhadap Nezara viridula Linnaeus (Heteroptera: Pentatomidae) dengan menjadi kurang aktif dan hanya sebentar kontak dengan inangnya (Salerno et al. 2002). Deltametrin konsentrasi subletal mempengaruhi komunikasi seksual parasitoid jantan dan betina Trichogramma brassicae Bezdenko (Hymenoptera: Trichogrammatidae) (Delpuech et al. 1999; Delpuech et al. 2001). Insektisida lain (klorpirifos) yang target kerjanya mengganggu sistem syaraf juga dilaporkan mempengaruhi perubahan perilaku parasitoid terhadap senyawa kimia inang (Komeza et al. 2001), feromon seksual (Delpuech et al. 1998) dan bau habitat inang (Rafalimanana et al. 2002). Parasitoid A. nilaparvatae dapat terpapar beberapa insektisida melalui kontak dengan serangga inang dan tanaman yang baru diaplikasikan dengan insektisida serta dapat menyebabkan pengaruh negatif pada parasitoid (Wang et al. 2008). Oleh karena itu, sangat penting untuk mempelajari efek insektisida dalam menjawab perubahan perilaku pencarian inang. Perilaku pencarian inang mencakup orientasi terhadap bau inang atau tanaman mengandung inang (Vinson 1998).

Penelitian ini bertujuan untuk mengetahui pengaruh insektisida deltametrin yang diaplikasikan pada imago parasitoid dan tanaman padi terhadap perilaku orientasi parasitoid $A$. nilaparvatae.

\section{BAHAN DAN METODE}

\section{Lokasi dan waktu penelitian}

Penelitian dilaksanakan di Laboratorium Toksikologi Pestisida dan rumah kaca, Jurusan 
Hama dan Penyakit Tumbuhan, Fakultas Pertanian, Universitas Gadjah Mada (UGM), Yogyakarta pada tahun 2012.

\section{Persiapan populasi dan pembiakan $N$. lugens}

Populasi $N$. lugens dibiakkan pada bibit padi menggunakan metode yang sudah digunakan di Laboratorium Toksikologi Pestisida sejak tahun 1985. Bibit padi umur tujuh hari dalam stoples plastik (diameter atas $20 \mathrm{~cm}$ dan bawah $17 \mathrm{~cm}$, tinggi $20 \mathrm{~cm}$ ) dengan sedikit media air diinfestasi dengan 100 pasang imago $N$. lugens. $N$. lugens dipelihara sampai bibit padi menguning. Jika padi sudah mulai menguning, penggantian pakan (bibit padi baru) dilakukan dengan mengangkat tanaman lama dan diletakkan di atas bibit baru dengan cara membaliknya.

\section{Persiapan populasi dan perbanyakan parasitoid A. nilaparvatae}

Populasi awal parasitoid A. nilaparvatae diperoleh dengan cara pemerangkapan di lapangan. Pemerangkapan dilakukan dengan menggunakan tanaman padi umur satu bulan yang sudah mengandung telur $N$. lugens umur dua hari. Parasitoid yang muncul dipelihara dan diperbanyak dalam kotak plastik menurut metode yang digunakan oleh Meilin et al. (2012). Pada bagian dasar kotak plastik terdapat baki plastik ukuran $15 \mathrm{~cm} \times 20 \mathrm{~cm} \times 3 \mathrm{~cm}$ dengan bibit padi umur tujuh hari dan mengandung telur $N$. lugens umur 2 hari. Kotak plastik berupa kurungan berukuran $14 \mathrm{~cm} \mathrm{x}$ $18,5 \mathrm{~cm} \times 18,5 \mathrm{~cm}$ yang terbuat dari plastik mika (tebal 0,6 mm) dengan sisi depan bagian tengah atas diberi tabung reaksi (panjang $10 \mathrm{~cm}$, diameter $1 \mathrm{~cm}$ ). Tabung reaksi berfungsi untuk memudahkan panen parasitoid. Saat panen, tabung reaksi diarahkan ke cahaya dan semua parasitoid yang muncul masuk kedalam tabung reaksi karena parasitoid ini bersifat fototaksis positif. Parasitoid dipanen dengan mengganti tabung reaksi setiap kali panen. Pada sisi lain (berlawanan dengan tabung reaksi) diberi kain kasa $(6 \mathrm{~cm} \times 10 \mathrm{~cm})$ untuk aerasi.

Kotak plastik diinfestasi 100 imago $N$. lugens siap bertelur pada bibit padi umur satu minggu dalam baki plastik. $N$. lugens dibiarkan dalam kotak sampai semua mati. Satu hari kemudian, ke dalam masing-masing kotak plastik diinfestasi 50 parasitoid. Pada setiap dinding kotak plastik dioleskan madu sebagai pakan parasitoid. Pemunculan parasitoid pertama terjadi pada hari ke-9 dan pemunculan terakhir pada hari ke-13 setelah infestasi.

\section{Persiapan insektisida}

Insektisida yang digunakan adalah insektisida dengan bahan aktif deltametrin.

\section{Pengujian toksisitas deltametrin terhadap $A$. nilaparvatae}

Pengujian toksisitas dilakukan dengan menggunakan metode kontak dan metode oral (Desneux et al. 2006b). Pengujian dilakukan untuk menentukan nilai $\mathrm{LC}_{50}$ dan konsentrasi subletal deltametrin terhadap parasitoid A. nilaparvatae. Pengujian dilakukan dengan menggunakan metode kontak (Desneux et al. 2006b) yang dimodifikasi pada konsentrasi yang digunakan. Berdasarkan hasil uji pendahuluan, enam konsentrasi $(0,015625-$ $4 \mathrm{ppm}$ dalam aseton) dipilih untuk memperoleh mortalitas parasitoid 5-95\%. Seri konsentrasi dibuat dengan pengenceran empat kali. Setiap perlakuan menggunakan 10 imago parasitoid, dan diulang sebanyak empat kali. Sebagai kontrol digunakan aseton. Metode kontak diaplikasikan menggunakan tabung reaksi (diameter $1,3 \mathrm{~cm}$, panjang $10 \mathrm{~cm}$ ). Tabung reaksi dibasahi dengan masing-masing seri konsentrasi sebanyak $0,1 \mathrm{ml}$ larutan. Tabung reaksi diputar sehingga seluruh permukaan dalam terkena larutan deltametrin dan kemudian dibiarkan menguap selama satu jam. Sepuluh parasitoid betina dimasukkan dalam tabung reaksi dan dibiarkan terpapar insektisida selama satu jam. Parasitoid kemudian dipindahkan pada tabung reaksi bersih yang berisi bibit tanaman padi yang telah diinfestasi telur $N$. lugens umur dua hari dan larutan madu $10 \%$ pada alumunium foil $(0,5 \mathrm{~cm} \times 4 \mathrm{~cm})$. Tabung reaksi ditutup dengan kain kassa halus. Mortalitas parasitoid diamati 24 jam setelah perlakuan. Untuk kontrol, parasitoid diperlakukan sama tanpa penggunaan insektisida. Metode oral diaplikasikan dengan membuat larutan insektisida deltametrin sebanyak delapan seri konsentrasi (0,0002-200 ppm) dengan pengenceran 10 kali. Larutan insektisida tersebut dicampur dengan larutan madu 10\% dengan perbandingan $1: 9$. Campuran larutan dioleskan secara merata pada 
alumunium foil $(0,5 \mathrm{~cm} \mathrm{x} 4 \mathrm{~cm})$ pada salah satu sisi, selanjutnya dimasukkan dalam tabung reaksi (diameter $1 \mathrm{~cm}$, panjang $10 \mathrm{~cm}$ ). Sepuluh parasitoid (umur 1 hari) dimasukkan ke dalam tabung reaksi dan dibiarkan selama satu jam. Selanjutnya, parasitoid dipindahkan pada tabung reaksi bersih yang berisi bibit tanaman padi yang telah diinfestasi telur $N$. lugens umur dua hari dan diberi larutan madu 10\% tanpa insektisida pada alumunium foil $(0,5 \mathrm{~cm} \times 4 \mathrm{~cm})$. Tabung reaksi ditutup dengan kain kasa halus. Analisis probit (Finney 1971) dilakukan dengan menggunakan perangkat lunak SAS 9.3.1 Portable. Mortalitas parasitoid diamati 24 jam setelah perlakuan. Data hanya akan dianalisis apabila mortalitas pada kontrol $<20 \%$.

Pengujian pengaruh insektisida deltametrin konsentrasi subletal terhadap perilaku orientasi parasitoid $A$. nilaparvatae

Studi ini bertujuan untuk mengetahui pengaruh insektisida deltametrin konsentrasi subletal $\left(\mathrm{LC}_{10}\right.$ dan $\mathrm{LC}_{40}$ ) dari metode kontak yang diaplikasikan pada imago betina $A$. nilaparvatae terhadap perilaku orientasi. Percobaan ini mengacu pada metode yang digunakan oleh Lou et al. (2005a; 2005b; 2006), Wang et al. (2008), Liu et al. (2010) dengan menggunakan olfaktometer.

Deskripsi dan cara kerja penggunaan olfaktometer. Perilaku orientasi diamati dua jam setelah perlakuan insektisida menggunakan olfaktometer tabung-Y (Lou et al. 2005a; 2005b; 2006), Wang et al. (2008), Liu et al. (2010) yang dimodifikasi. Olfaktometer terdiri atas tabung gelas berbentuk Y (diameter 1,3 cm), pada dasar dan dua tangan tabung $\mathrm{Y}$ masing-masing panjangnya $10 \mathrm{~cm}$. Masing-masing ujung tangan $\mathrm{Y}$ dihubungkan ke tabung sumber bau (sebuah silinder gelas $10 \mathrm{~cm}$ x $22 \mathrm{~cm}$ ). Sebuah aliran udara dari sumber aerator dengan kapasitas 1,5 1/menit (Gong Yang Bang HP-100 Sun-Sun, Zhe Jiang Sensen Industry Co. LTD) melewati tabung gelas dengan arang aktif sebagai filter dan hasil saringannya dibagi dua dengan menggunakan selang plastik bening. Masing-masing aliran udara melewati sebuah flowmeter (series RMA, Rate Master Flowmeter, Dwyer Instrument Inc., USA) dengan kapasitas aliran udara $150 \mathrm{ml} / \mathrm{menit}$, selanjutnya melewati tabung gelas berisi air berfungsi sebagai humidifier dan kemudian melewati kontainer gelas sumber bau sebelum sampai ke tabung-Y. Olfaktometer tabung-Y ditempatkan dalam kotak yang dicat putih dengan sumber cahaya buatan (lampu 20 watt) yang ditempatkan pada bagian depan atas tabung-Y (Gambar 1). Semua pengujian dilakukan antara pukul 09:00-17:00 WIB. Suhu ruang selama percobaan adalah $27-31{ }^{\circ} \mathrm{C}$ dengan kelembaban $64-84 \%$.

Sumber bau. Sepasang sumber bau yang diuji adalah 1) tanaman padi umur satu bulan yang mengandung telur, 100 betina, dan nimfa $N$. lugens; 2) tanaman padi saja mewakili tanaman padi yang sehat. Batang tanaman padi dipotong pada bagian pangkal yang berada diatas permukaan tanah, kemudian dicuci dan bagian pangkal tersebut diberi kapas basah, selanjutnya dimasukkan dalam wadah sumber bau dan ditutup rapat. Setelah dua

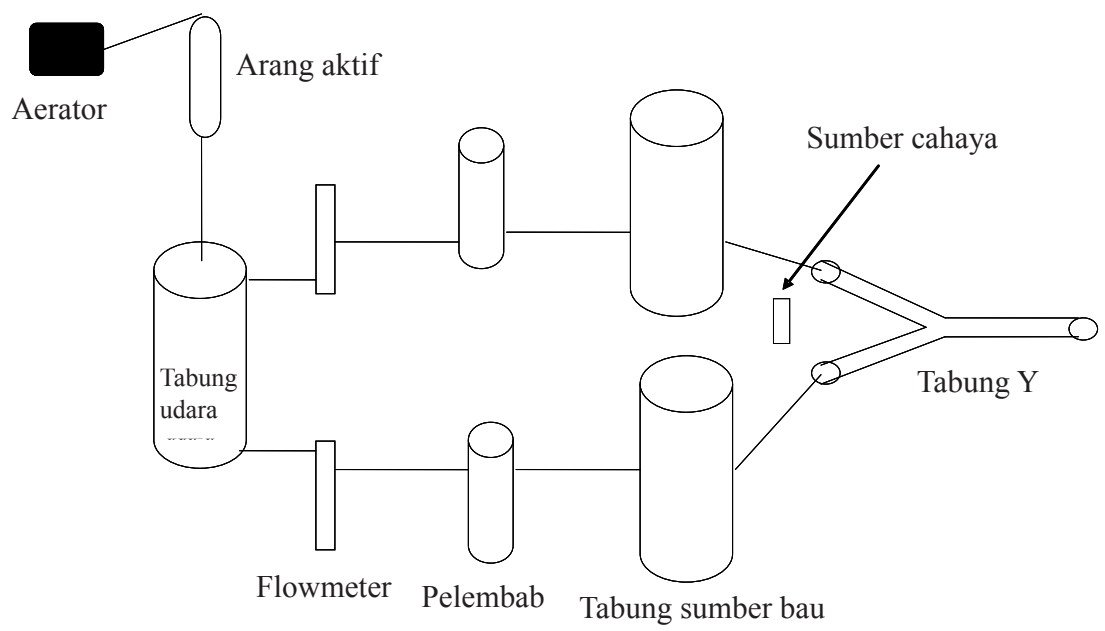

Gambar 1. Skematik rancangan pengujian perilaku orientasi parasitoid Anagrus nilaparvatae dengan menggunakan olfaktometer tabung-Y. 
jam pengujian, tanaman diganti dengan tanaman baru dengan perlakuan yang sama.

Uji perilaku orientasi parasitoid $A$. nilaparvatae pada olfaktometer. Parasitoid yang digunakan adalah parasitoid yang sudah diperbanyak sampai generasi ke-28 di Laboratorium Toksikologi Pestisida, UGM. Parasitoid betina diperlakukan insektisida deltametrin konsentrasi subletal $\left(\mathrm{LC}_{10}\right.$ dan $\left.\mathrm{LC}_{40}\right)$ dan sebagai kontrol parasitoid diperlakukan dengan aseton. Parasitoid yang hidup setelah perlakuan (selama 1 jam), dipindahkan ke dalam tabung reaksi bersih yang telah diberi larutan madu $10 \%$ pada alumunium foil $(0,5 \mathrm{~cm} \mathrm{x} 4 \mathrm{~cm})$. Dua jam kemudian, parasitoid digunakan untuk pengujian. Satu betina parasitoid secara individu dimasukkan dalam dasar olfaktometer tabung-Y, dibiarkan memilih dan ditunggu selama 10 menit untuk jalan sampai ke tangan Y. Parasitoid dikategorikan memilih, jika melintasi salah satu tangan $\mathrm{Y}$ sepanjang $7 \mathrm{~cm}$ dari dasar tangan dan tinggal selama lebih kurang satu menit pada lokasi tersebut. Jika selama 10 menit parasitoid tidak melakukan pemilihan maka dianggap tidak ada respons (Lou et al. (2005a; 2005b; 2006), Wang et al. (2008), Liu et al. (2010)). Setelah satu kali pengujian, olfaktometer tabung-Y diganti dengan olfaktometer tabung Y-lainnya. Olfaktometer tabung-Y di cuci dengan alkohol 70 persen dan dikeringkan. Jumlah parasitoid betina yang digunakan untuk uji per individu sebanyak 12 parasitoid betina (merupakan 12 ulangan), sedangkan untuk uji kelompok, setiap kelompok terdiri atas 8-14 parasitoid, dan diulang empat kali.

Pengujian pengaruh insektisida deltametrin pada tanaman padi terhadap perilaku orientasi parasitoid $A$. nilaparvatae

Penelitian ini mengacu kepada metode yang digunakan oleh Lou et al. (2005a; 2005b; 2006), Wang et al. (2008), Liu et al. (2010) menggunakan olfaktometer yang sama dengan penelitian pengaruh insektisida deltametrin konsentrasi subletal terhadap perilaku orientasi parasitoid $A$. nilaparvatae.

Sumber bau. Pada percobaan ini sumber bau adalah tanaman padi yang diperlakukan insektisida deltametrin dengan konsentrasi rekomendasi (12,5 ppm) dan setengah rekomendasi (6,25 ppm) yang diaplikasikan pada 3 jam, 1 hari, 3 hari, dan 7 hari sebelum pengujian/parasitasi parasitoid. Sebagai kontrol (K) digunakan air. Tanaman padi yang digunakan sebagai sumber bau sudah mengandung telur $N$. lugens umur satu hari dan 100 individu kompleks $N$. lugens (betina, jantan dan nimfa $N$. lugens). Batang tanaman padi dipotong pada bagian pangkal yang berada diatas permukaan tanah, kemudian dicuci dan bagian pangkal tersebut diberi kapas basah, selanjutnya dimasukkan dalam wadah sumber bau dan ditutup rapat. Setelah dua jam pengujian, tanaman diganti dengan tanaman baru dengan perlakuan yang sama.

Uji perilaku orientasi parasitoid $A$. nilaparvatae pada olfaktometer. Parasitoid yang digunakan adalah parasitoid yang sudah dibiakkan sampai generasi ke-29 di Laboratorium Toksikologi Pestisida, UGM. Parasitoid betina yang digunakan tidak diperlakukan insektisida. Respons perilaku orientasi diamati dengan menggunakan metode, seperti pada penelitian pengaruh insektisida deltametrin konsentrasi subletal terhadap perilaku orientasi parasitoid, dan pasangan sumber bau yang digunakan adalah perlakuan $12,5 \mathrm{ppm}$ dan $\mathrm{K}$; $6,25 \mathrm{ppm}$ dan $\mathrm{K} ; 12,5 \mathrm{ppm}$ dan 6,25 ppm, masingmasing percobaan dilakukan pada hari yang berbeda untuk masing-masing perlakuan waktu aplikasi insektisida pada tanaman padi ( 3 jam, 1 hari, 3 hari dan 7 hari). Jumlah parasitoid yang diperlakukan per ulangan adalah 10 parasitoid betina (umur 1 hari). Percobaan dilakukan dengan empat ulangan.

\section{Analisis data}

Perbedaan respons perilaku orientasi parasitoid dianalisis menggunakan uji Chi-Square $\left(\chi^{2}\right)$ dengan menggunakan perangkat lunak SAS 9.3.1 Portable.

\section{HASIL}

\section{Toksisitas deltametrin terhadap A. nilaparvatae}

Hasil analisis probit menunjukkan bahwa aplikasi deltametrin dengan metode kontak menghasilkan mortalitas yang semakin meningkat dengan meningkatnya konsentrasi deltametrin. $\mathrm{LC}_{50}$ deltametrin terhadap parasitoid $A$. nilaparvatae dengan metode kontak (6,935 ppm) tidak 
berbeda nyata dengan $\mathrm{LC}_{50}$ dengan metode oral (9,899 ppm) karena nilai FL 95\% tumpang tindih (overlapping). Dengan metode kontak diperoleh $\mathrm{LC}_{10}$ adalah $0,023 \mathrm{ppm}$ dan $\mathrm{LC}_{40}$ adalah $2,235 \mathrm{ppm}$, sedangkan dengan metode oral diperoleh $\mathrm{LC}_{10}$ adalah 0,001 ppm dan $\mathrm{LC}_{40}$ adalah 1,685 ppm, (Tabel 1). $\mathrm{LC}_{10}$ dan $\mathrm{LC}_{40}$ dengan metode kontak kemudian dipilih untuk digunakan untuk pengujian berikutnya.

\section{Pengaruh insektisida deltametrin konsentrasi} subletal terhadap perilaku orientasi parasitoid A. nilaparvatae

Perlakuan insektisida deltametrin konsentrasi subletal $\left(\mathrm{LC}_{10}\right.$ dan $\left.\mathrm{LC}_{40}\right)$ pada A. nilaparvatae menyebabkan hampir $50 \%$ A. nilaparvatae menjadi tidak respons terhadap bau dibandingkan dengan kontrol, saat pengujian dilakukan terpisah untuk setiap individu. Pada pelepasan parasitoid secara kelompok, beberapa parasitoid juga menunjukkan tidak respons terhadap bau, jumlah parasitoid $A$. nilaparvatae yang respons terhadap bau tanaman padi yang mengandung kompleks $N$. lugens selalu lebih banyak dibandingkan yang respons hanya tanaman padi saja, baik dalam kondisi ada perlakuan deltametrin atau tidak (kontrol) (Tabel 2).

Pengaruh residu insektisida deltametrin pada tanaman padi terhadap perilaku orientasi parasitoid $A$. nilaparvatae

Residu deltametrin pada tanaman padi yang diaplikasi konsentrasi 12,5 ppm mengganggu secara nyata perilaku orientasi parasitoid $A$. nilaparvatae dalam mencari inang (telur $N$. lugens) (Gambar 2a). Namun demikian, ketika konsentrasi deltametrin diturunkan manjadi 6,25 ppm maka residu yang diaplikasikan tidak lagi berpengaruh terhadap perilaku orientasi $A$. nilaparvatae (Gambar 2b).

Ketika kedua tanaman diperlakukan dengan konsentrasi 12,5 ppm dan 6,25 ppm maka residu yang tertinggi pada 3 jam, 1 hari dan 3 hari setelah aplikasi masih mampu mempengaruhi orientasi parasitoid dan parasitoid memilih pada tanaman padi dengan konsentrasi residu lebih rendah (Gambar 2c). Namun demikian,

Tabel 1. Toksisitas insektisida deltametrin terhadap parasitoid Anagrus nilaparvatae dengan metode kontak dan oral

\begin{tabular}{lll}
\hline \multirow{2}{*}{ Parameter } & \multicolumn{2}{c}{ Metode } \\
\cline { 2 - 3 } & \multicolumn{1}{c}{ Kontak $^{*}$} & \multicolumn{1}{c}{ Oral** } \\
\hline Jumlah serangga uji & 360 & 320 \\
$\mathrm{LC}_{10}(95 \% \mathrm{FL})(\mathrm{ppm})$ & $0,023(0,002-0,064)$ & $0,001(0,000-0,007)$ \\
$\mathrm{LC}_{40}(95 \% \mathrm{FL})(\mathrm{ppm})$ & $2,235(0,962-2,172)$ & $1,685(0,530-6,383)$ \\
$\mathrm{LC}_{50}(95 \% \mathrm{FL})(\mathrm{ppm})$ & $6,935(2,331-81,901)$ & $9,899(2,868-53,860)$ \\
Slope $\pm \mathrm{SE}$ & $0,51 \pm 0,05$ & $0,35 \pm 0,05$ \\
\hline
\end{tabular}

*Parasitoid dewasa dimasukkan ke dalam tabung reaksi yang telah diperlakukan dengan deltametrin

**Parasitoid dewasa diberi larutan madu 10\% yang dicampur deltametrin

SE: standar eror; FL: fiducial limit; ppm: part per million

Tabel 2. Respon perilaku Anagrus nilaparvatae yang hidup setelah perlakuan deltametrin konsentrasi subletal terhadap senyawa volatil tanaman padi dan komplek Nilaparvata lugens

\begin{tabular}{|c|c|c|c|c|c|}
\hline \multirow[b]{2}{*}{ Perlakuan* } & \multirow{2}{*}{$\begin{array}{c}\text { Jumlah } \\
\text { parasitoid uji }\end{array}$} & \multirow{2}{*}{$\begin{array}{c}\text { Jumlah } \\
\text { parasitoid tidak } \\
\text { respon }\end{array}$} & \multicolumn{2}{|c|}{ Jumlah parasitoid tertarik 'odor' } & \multirow{2}{*}{$\begin{array}{c}\text { Nilai } \\
\chi^{2}\end{array}$} \\
\hline & & & Tanaman padi & $\begin{array}{c}\text { Tanaman padi }+ \\
\text { kompleks } N \text {. lugens }\end{array}$ & \\
\hline & & $(\%)$ & $(\%)$ & $(\%)$ & \\
\hline Kontrol & 12 & 0 & 16,67 & 83,33 & $5,33 * *$ \\
\hline $\mathrm{LC}_{10}$ & 12 & 50,00 & 16,67 & 33,33 & 2,00 \\
\hline \multirow[t]{2}{*}{$\mathrm{LC}_{40}$} & 12 & 41,67 & 16,67 & 41,67 & 1,50 \\
\hline & & $(\%)$ & $(\%)$ & $(\%)$ & \\
\hline Kontrol & 40 & 0 & 27,50 & 72,50 & $8,10 * *$ \\
\hline $\mathrm{LC}_{10}$ & 34 & 29,41 & 23,52 & 47,05 & 3,06 \\
\hline $\mathrm{LC}_{40}^{10}$ & 32 & 31,25 & 21,87 & 46,87 & 3,06 \\
\hline
\end{tabular}

*Individu: A. nilaparvatae dilepas secara individu dalam olfaktometer Y.

Kelompok: A. nilaparvatae dilepas secara berkelompok dalam olfaktometer Y

**menunjukkan berbeda nyata pada $\alpha=0,01, \mathrm{db}=1, \chi^{2} 0,01=3,8$ 
semakin sedikit jumlah residu (semakin lama waktu aplikasi) maka pengaruh terhadap perilaku orientasi semakin rendah dan tidak signifikan lagi pada residu 7 hari (Gambar 2 C).

\section{PEMBAHASAN}

Hasil nilai $\mathrm{LC}_{10}$ dan $\mathrm{LC}_{40}$ insektisida deltametrin konsentrasi subletal terhadap parasitoid A. nilaparvatae dengan metode kontak digunakan dalam penelitian ini. Konsentrasi dengan metode ini digunakan karena masing-masing nilai konsentrasi pada metode kontak dan oral menunjukkan nilai 95\% FL yang tumpang tindih yang menunjukkan tidak berbeda nyata. Metode paparan pestisida dengan aplikasi topikal, oral, residu, atau studi lapangan telah banyak digunakan untuk melihat responsnya terhadap musuh alami (Longley \& Jepson 1996; Longley 1999; Desneux et al. 2005; Wang et al. 2008; Liu et al. 2010; Fernandes et al. 2010). Masing-masing pendekatan memberikan informasi terhadap dampak pestisida terhadap musuh alami. Aplikasi kontak dan oral menyediakan pengetahuan tentang efek langsung dan toksisitas akut terhadap serangga. Paparan dosis subletal dan letal insektisida pada musuh alami dapat memberikan informasi penting tentang kompatibilitas pengendalian kimiawi dan hayati (Desneux et al. 2007). Efek subletal imidakloprid pada parasitoid yang dipaparkan dengan metode yang berbeda (oral, topikal) menunjukkan perbedaan respon terhadap A. nilaparvatae (Liu et al. 2010).

Penelitian ini menunjukkan bahwa insektisida deltametrin konsentrasi subletal $\left(\mathrm{LC}_{10}\right.$ dan $\left.\mathrm{LC}_{40}\right)$

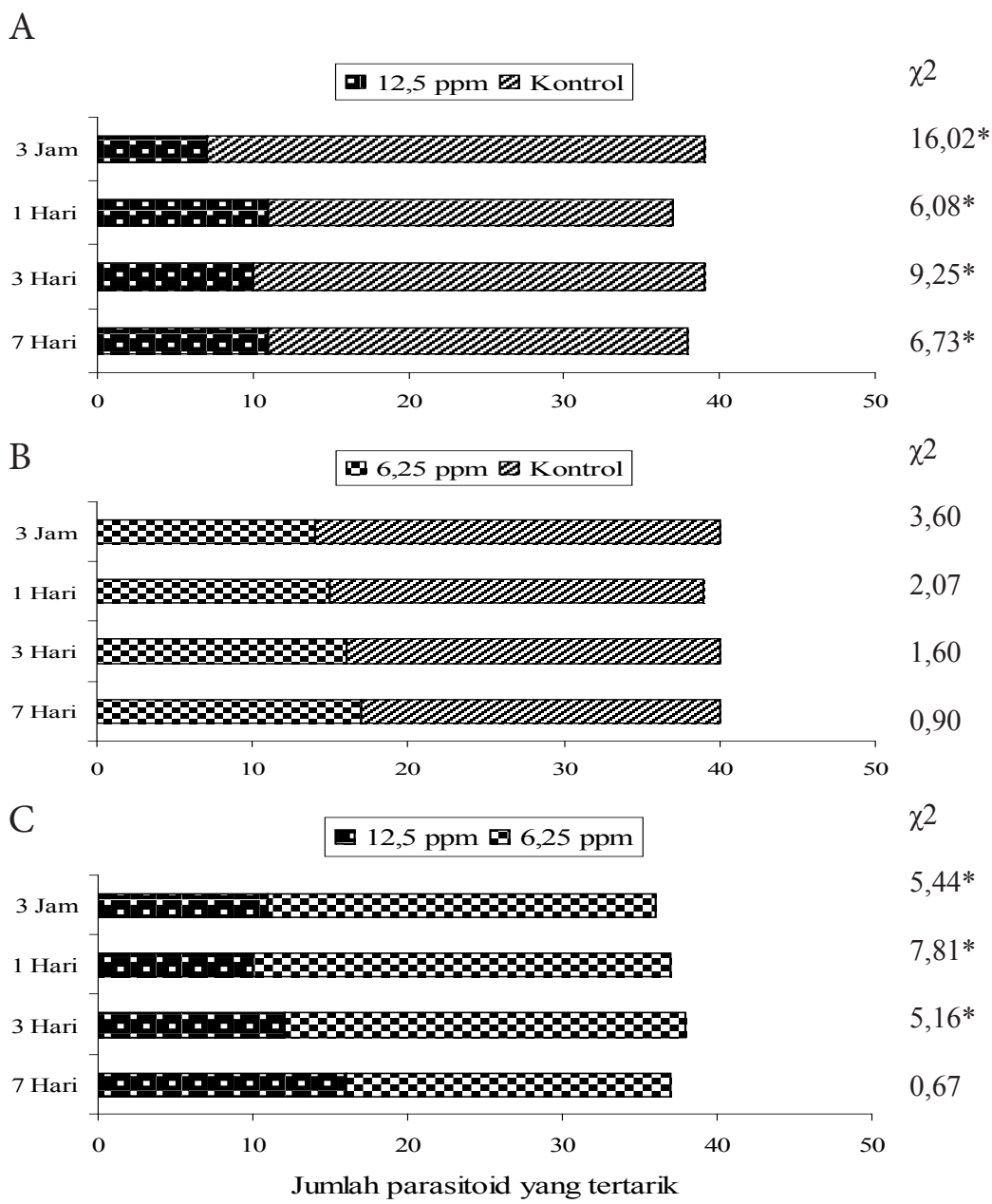

Gambar 2. Jumlah imago betina Anagrus nilaparvatae yang tertarik pada senyawa volatil yang dilepaskan dari pasangan bau pada tanaman padi. A: tanaman padi diperlakukan dengan deltametrin konsentrasi 12,5 ppm dan kontrol (air); B: tanaman padi diperlakukan dengan konsentrasi $6,25 \mathrm{ppm}$ dan kontrol (air); C: tanaman padi diperlakukan dengan konsentrasi 12,5 ppm dan 6,25 ppm. Waktu adalah waktu setelah perlakuan insektisida deltametrin. *: menunjukkan berbeda nyata pada $\alpha=0,01, \mathrm{db}=1, \chi^{2} 0,01=3,84$. 
pada imago parasitoid $A$. nilaparvatae menurunkan kemampuan perilaku orientasinya untuk tertarik terhadap bau tanaman padi saja atau tanaman padi- $N$. lugens. Pada kontrol, A. nilaparvatae lebih tertarik pada tanaman padi- $N$. lugens yang merupakan tanaman yang mengalami kerusakan oleh $N$. lugens. A. nilaparvatae betina tidak tertarik terhadap senyawa volatil tanaman padi sehat (tidak diserang). Hasil ini konsisten dengan penelitian sebelumnya bahwa $A$. nilaparvatae tertarik terhadap senyawa volatil yang dilepas dari tanaman yang mengandung $N$. lugens (Lou et al. 2005b). Tanaman padi yang diinfestasi dengan $N$. lugens mengeluarkan senyawa volatil (linalool, [3E]-4,8-dimethyl-1,3,7-nonatriene,indole) yang tidak terdeteksi pada tanaman padi sehat atau yang dirusak secara mekanis (Xu et al. 2002). Tanaman padi sehat mengeluarkan senyawa volatil dengan proporsi yang lebih sedikit dibandingkan dengan tanaman padi yang diserang $N$. lugens (Lou et al. 2005). Diduga bahwa, senyawa volatil (linalool,[3E]-4,8-dimethyl-1,3,7-nonatriene, indole) yang dikeluarkan oleh tanaman padi yang diinfestasi dengan $N$. lugens dan jumlah senyawa volatil mempengaruhi orientasi oleh parasitoid $A$. nilaparvatae. Penelitian lain juga menunjukkan bahwa betina Aphidius ervi Haliday yang terpapar residu insektisida deltametrin, tertahan kemampuannya untuk melakukan orientasi terhadap bau inang (senyawa volatil inang) (Desneux et al. 2006b). Deltametrin dosis subletal meningkatkan perilaku arrestment pada jantan Trichogramma dalam merespon feromon yang dipancarkan oleh serangga betina (Delpuech et al. 1999). Betina T. basalis yang terpapar deltametrin dosis rendah menurun kecepatan jalannya (Salerno et al. 2002). Sebaliknya, Desneux et al. (2004) menjelaskan bahwa A. ervi yang terpapar insektisida mengalami perubahan perilaku orientasi dalam olfaktometer.

Adanya parasitoid yang tidak respon diduga karena mengalami gangguan dalam mendeteksi bau yang dikeluarkan tanaman atau bau hasil interaksi tanaman padi-N.lugens. Kemampuan mendeteksi bau diasosiasikan terhadap perilaku penciuman yang sepenuhnya bergantung pada transmisi syaraf. Sistem syaraf merupakan target dari insektisida neurotoksik yang dapat mengalami gangguan pembukaan sodium channel 136 pada membran neuron dalam waktu yang lama (Soderlund \& Bloomquist 1989) atau terganggunya persepsi sinyal sensorik (olfaktori, gustatori, dan isyarat fisik) atau gangguan fungsi gerak pada serangga (Delpuech et al. 1999; Salerno et al. 2002).

Kurangnya pemilihan $A$. nilaparvatae terhadap tanaman padi yang diaplikasi dengan insektisida deltametrin konsentrasi tinggi dan rendah kemungkinan karena perubahan jumlah senyawa volatil yang dilepas dari tanaman sebagai akibat penutupan oleh insektisida. Kawazu et al. (2010) menunjukkan fenomena yang sama pada Cotesia vestalis (Haliday) yang terhambat perilaku pencarian makan akibat aplikasi permetrin pada tanaman. Selain itu, perubahan fisiologi dan biokimia tanaman setelah aplikasi insektisida pada tanaman padi (Wu et al. 2001; Qiu et al; 2004; Ratna 2011) diduga memberikan kontribusi pada penghambatan perilaku parasitoid dalam menemukan inangnya.

Kenyataan yang terjadi di lapangan, aplikasi pestisida selalu dilakukan oleh petani. Hal ini akan mengakibatkan bahwa konsentrasi subletal itu pasti ada dengan berjalannya waktu aplikasi pestisida sehingga ada suatu saat dimana lapangan akan penuh dengan efek subletal ini dan bisa mengganggu parasitoid. Jadi pengaruh pestisida pada parasitoid itu panjang, bukan hanya membunuh pada konsentrasi letal, tapi juga mengganggu perilaku pada konsentrasi subletal. Selama ada residu pestisida pada tanaman padi dan atau lingkungan sekitar maka kinerja parasitoid dalam memarasit inangnya akan terganggu.

\section{KESIMPULAN}

Deltametrin konsentrasi subletal pada parasitoid melalui metode kontak $[0,023 \mathrm{ppm}$ $\left(\mathrm{LC}_{10}\right)$ dan 2,235 ppm $\left(\mathrm{LC}_{40}\right)$ ], dan pada tanaman padi (12,5 dan 6,25 ppm) menurunkan kemampuan parasitoid $A$. nilaparvatae untuk tertarik terhadap bau (senyawa volatil) tanaman inang- $N$. lugens. Semakin tinggi konsentrasi deltametrin baik yang diperlakukan pada parasitoid maupun tanaman maka pengaruhnya terhadap perubahan orientasi semakin besar dan gangguan terhadap orientasi A. nilaparvatae dalam menemukan inang semakin 
besar. Efek subletal insektisida pada parasitoid dan tanaman padi akhirnya menyebabkan parasitoid A. nilaparvatae menjadi kurang efektif sebagai agen pengendali hayati di lapangan karena menurunnya performa dalam memarasit dan menyerang inangnya.

\section{DAFTAR PUSTAKA}

Bayram A, Salerno G, Onofri A, Conti E. 2010. Sublethal effects of two pyrethroids on biological parameters and behavioral responses to host cues in the egg parasitoid Telenomus busseolae. Biological Control 53:153-160. doi: http:// dx.doi.org/10.1016/j.biocontrol.2009.09.012.

Delpuech JM, Legallet B, Terrier O, Fouillet P. 1999. Modifications of the sex pheromonal communication of Trichogramma brassicae by a sublethal dose of deltamethrin. Chemosphere 38:729-739. doi: http://dx.doi.org/10.1016/S00 45-6535(98)00310-5.

Delpuech JM, Legallet B, Fouillet P. 2001. Partial compensation of the sublethal effect of deltamethrin on the sex pheromonal communication of Trichogramma brassicae. Chemosphere 42:985-991. doi: http://dx.doi.org/ 10.1016/S0045-6535(00)00110-7.

Desneux N, Pham-Delegue M, Kaiser L. 2003. Effects of sub-lethal and lethal doses of lambdacyhalotrin on oviposition experience and hostsearching behaviour of a parasitic wasp, Aphidius ervi. Pest Management Science 60:381-389. doi: http://dx.doi.org/10.1002/ps.822.

Desneux N, Rafalimanana H, Kaiser L. 2004. Doseresponse relationship in lethal and behavioural effects of different insecticides on the parasitic wasp Aphidius ervi. Chemosphere 54:619-627. doi: http://dx.doi.org/10.1016/j.chemosphere. 2003.09.007.

Desneux N, Fauvergue X, Moncharmont F-XD, Kerhoas L, Ballanger Y, Kaiser L. 2005. Diaeretiella rapae limits Myzus persicae populations after applications of deltamethrin in oilseed rape. Journal of Economic Entomology 98:9-17. doi: http://dx.doi.org/10.1093/jee/98.1.9.

Desneux N, Ramirez-Romero R, Kaiser L. 2006a. Multistep bioassay to predict recolonization potential of emerging parasitoids after a pesticide treatment. Environmental Toxicology and Chemistry 25:2675-2682. doi: http://dx.doi. org/10.1897/05-562R.1.
Desneux N, Denoyelle R, Kaiser L. 2006b. A Multi-step bioassay to assess the effect of the deltamethrin on the parasitic wasp Aphidius ervi. Chemosphere 65:1697-1706. doi: http://dx.doi. org/10.1016/j.chemosphere.2006.04.082.

Desneux N, Decourtye A, Delpuech JM. 2007. The Sublethal effects of pesticides on beneficial arthropods. Annual Review of Entomology 52: 81-106. doi: http://dx.doi.org/10.1146/annurev. ento.52.110405.091440.

Fernandes FL, Bacci L, Fernandes MS. 2010. Impact and selectivity of insecticides to predators and parasitoids. Entomo Brasilis 3:1-10.

Haynes KF. 1988. Sublethal effects of neurotoxic insecticides on insect behaviour. Annual Review of Entomology 33:149-168. doi: http://dx.doi. org/10.1146/annurev.en.33.010188.001053.

Horgan F. 2009. Mechanisms of resistance: a major gap in understanding planthopper-rice interactions. In: Heong KL, Hardy B (Eds.), Planthoppers: New Threats to the Sustainability of Intensive Rice Production Systems in Asia. pp. 281-302. Los Baños: International Rice Research Institute.

Kawazu K, Shimoda T, Kobori Y, Kugimiya S, Mukuwa S, Suzuki Y. 2010. Inhibitory effects of permethrin on flight responses, host-searching, and foraging behaviour of Cotesia vestalis (Hymenoptera: Braconidae), a larva parasitoid of Plutella xylostella (Lepidoptera: Plutellidae). Journal of Applied Entomology 134:313-322. doi: http://dx.doi.org/10.1111/j.1439-0418.2009. 01482.x.

Komeja N, Fouillet P, Bouletreau M, Delpuech JM. 2001. Modification, by insecticide chlorpyrifos, of the behavioural responses to kairomones of a parasitoid wasp, Leptopilina boulardi. Archives of Environmental Contamination and Toxicology 41:436-442. doi: http://dx.doi.org/10.1007/s002 440010269.

Liu F, Bao SW, Song Y, Lu HY, Xu JX. 2010. Effects of imidacloprid on the orientation behaviour and parasitizing capacity of Anagrus nilaparvatae, an egg parasitoid of Nilaparvata lugens. BioControl 55:473-483. doi: http://dx.doi.org/10.1007/s105 26-010-9276-z.

Longley M, Jepson PC. 1996. The influence of insecticide residues on primary parasitoid and hyperparasitoid foraging behaviour in the laboratory. Entomologia Experimentalis et Applicata 81:259-269.

Longley M. 1999. A review of pesticide effects upon immature aphid parasitoids within mummified hosts. International Journal of Pest Management 
45:139-145. doi: http://dx.doi.org/10.1046/j.15 70-7458.1996.00095.x.

Lou YG, Du MH, Turlings TCJ, Cheng JA, Shan WF. 2005a. Exogenous application of jasmonic acid induces volatile emissions in rice and enhances parasitism of Nilaparvata lugens eggs by the parasitoid Anagrus nilaparvatae. Journal of Chemical Ecology 31:1985-2002. doi: http:// dx.doi.org/10.1007/s10886-005-6072-9.

Lou YG, Ma B, Cheng JA. 2005b. Attraction of the parasitod Anagrus nilaparvatae to rice volatiles induced by the rice brown planthopper Nilaparvata lugens. Journal of Chemical Ecology 31:2357-2372. doi: http://dx.doi.org/10.1007/ s10886-005-7106-z.

Lou Y, Hua X, Turling TCJ, Cheng J, Chen X, Ye G. 2006. Differences in induced volatile emissions among rice varieties result in differential attraction and parasitism of Nilaparvata lugens eggs by parasitoid Anagrus nilaparvatae in the field. Journal of Chemical Ecology 32:23752387. doi: http://dx.doi.org/10.1007/s10886-00 6-9151-7.

Meilin A, Trisyono YA, Marwoto E, Buchori D. 2012. Teknik perbanyakan massal parasitoid Anagrus nilaparvatae (Pang et Wang) (Hymenoptera: Mymaridae) menggunakan kotak plastik. Jurnal Entomologi Indonesia 9:7-13. doi: http://dx.doi. org/10.5994/jei.9.1.7.

Nordlund DA. 1994. Habitat location by Trichogramma. In: Wajnberg E, Hassan S (Eds.), Biological Control with egg parasitoids. pp. 155-163. UK: CAB International.

Polleti M, Maia AHN, Omoto C. 2007. Toxicity of neonicotinoid insecticides to Neoseiulus californicus and Phytoseiulus macropilis (Acari: Phytoseiidae) and their impact on fungtional response to Tetranychus urticae (Acari: Tetrabycidae). Biological Control 40:30-36. doi: http://dx.doi.org/10.1016/j.biocontrol.2006. 09.001.

Qiu ZH, Wu JC, Dong B, Li DH, Gu HN. 2004. Two-way effect of pesticides on zeatin riboside content in both rice leaves and roots. Crop Protection 23:1131-1136. doi: http://dx.doi.org/ 10.1016/j.cropro.2004.04.005.
Raflimanana H, Kaiser L, Delpuech JM. 2002. Stimulating effects of the insecticide chlorpyrifos on host searching and infestation efficacy of a parasitoid wasp. Pest Management Science 58: 321-328. doi: http://dx.doi.org/10.1002/ps.454.

Ratna Y. 2011. Mekanisme Resurjensi Wereng Batang Padi Cokelat Setelah Aplikasi Deltametrin Konsentrasi Subletal. Disertasi. Yogyakarta: Universitas Gadjah Mada.

Salerno G, Collazo S, Conti E. 2002. Sub-lethal effects of deltamethrin on walking behaviour and response to host kairomone of the egg parasitoid Trissolcus basalis. Pest Management Science 58: 663-668. doi: http://dx.doi.org/10.1002/ps.492.

Soderlund DM, Bloomquist JR. 1989. Neurotoxic actions of pyrethroid insecticides. Annual Review of Entomology 34:77-96. doi: http://dx.doi. org/10.1146/annurev.en.34.010189.000453.

Vinson SB. 1976. Host selection by insect parasitoids. Annual Review of Entomology 21: 109-133. doi: http://dx.doi.org/10.1146/annurev. en.21.010176.000545.

Vinson SB. 1998. The general host selection behaviour of parasitoid Hymenoptera and a comparison of initial strategies utilized by larvaphagous and oophagous species. Biological Control 11:79-96. doi: http://dx.doi.org/10.1006/ bcon.1997.0601.

Wang HY, Yang Y, Su JY, Shen JL, Gao CF, Zhu YC. 2008. Assesment of the impact of insecticides on Anagrus nilaparvatae (Pang et Wang) (Hymenoptera: Mymaridae), an egg parasitoid of the rice planthopper, Nilaparvata lugens (Hemiptera: Delphacidae). Crop Protection 27:514-522. doi: http://dx.doi.org/10.1016/j. cropro.2007.08.004.

Wu JC, Xu JX, Yuan SZ, Liu JL, Jiang YH, Xu JF. 2001. Pesticide-induced susceptibility of rice to brown planthopper Nilaparvata lugens. Entomologia Experimentalis Et Applicata 100:119-126. doi: http://dx.doi.org/10.1046/ j.1570-7458.2001.00854.x.

Xu T, Zhou Q, Xia Q, Zhang W, Zhang G, Gu D. 2002. Effects of herbivore-induced rice volatiles on the host selection behavior of brown planthopper, Nilaparvata lugens. Chinese Science Bulletin 47:1355-1360. 